\title{
Regulatory effect of dietary intake of chromium propionate on the response of monocyte-derived macrophages from Holstein cows in mid lactation
}

\author{
M. Garcia, ${ }^{*}$ Y. Qu, ${ }^{*}$ C. M. Scholte, ${ }^{*}$ D. O’Connor, $†$ W. Rounds, $†$ and K. M. Moyes ${ }^{* 1}$ \\ *Department of Animal and Avian Sciences, University of Maryland, College Park 20740 \\ †Kemin Industries Inc., Des Moines, IA 50317
}

\begin{abstract}
Chromium (Cr) has been reported to enhance immune function and improve insulin sensitivity and performance in beef and dairy cattle. However, its effect on bovine macrophage inflammatory and metabolic response is unknown. The objective of this study was to characterize the effect of dietary $\mathrm{Cr}$ on the inflammatory and metabolic response of polarized macrophages ex vivo. Twelve primiparous and 16 multiparous healthy Holstein cows in mid lactation (143 $\pm 37 \mathrm{~d}$ in milk) were enrolled in this study. Cows were fed a common total mixed ration once per day that was top-dressed with $200 \mathrm{~g}$ of ground corn containing 1 of 2 dietary treatments: control (CTL, no $\mathrm{Cr}$ supplementation) or Cr propionate (CrP, $8 \mathrm{mg}$ of $\mathrm{Cr} /$ cow per day) for $35 \mathrm{~d}$. At d 1, 17, and 35 of treatment, blood monocytes were isolated and cultured to obtain 3 monocyte-derived macrophage (MDM) phenotypes: M0 (non-polarized), M1 (pro-inflammatory; IFN- $\gamma$ polarized) and M2 (anti-inflammatory; IL-4 polarized). The experiment was set in a randomized complete block design. Neither dry matter intake nor milk yield was affected by treatment. Plasma concentrations of metabolites and the metabolic and inflammatory response of MDM in spent media were not affected by treatment. Neither the whole blood cell population nor the specific proportion of leukocytes was affected by the main effect of treatment. However, we did observe a trend for fewer circulating neutrophils in cows fed $\mathrm{CrP}$ than in cows fed CTL for $35 \mathrm{~d}$, which may be partly attributable to a greater influx of neutrophils into peripheral tissues, a reduced pro-inflammatory response during disease, or both; this warrants future study. Expression of $I G F I$ was increased in MDM-M0, and expression of CXCL11 tended to increase in MDM-M2 from cows fed CrP compared with cows fed CTL. Expression of SLC2A3
\end{abstract}

Received September 30, 2016.

Accepted April 2, 2017.

${ }^{1}$ Corresponding author: kmoyes@umd.edu also tended to increase in MDM-M2 from cows fed $\mathrm{CrP}$ compared with cows fed CTL at $17 \mathrm{~d}$. Our results suggest that $\mathrm{CrP}$ has minimal effect on the inflammatory and metabolic response of MDM for Holstein dairy cows in mid lactation. Future studies are warranted to evaluate the differential regulation of $\mathrm{Cr}$ on the inflammatory and metabolic response of leukocytes from dairy cows at different stages of lactation and parity.

Key words: chromium propionate, Holstein cows, immune function, monocyte-derived macrophage

\section{INTRODUCTION}

Lactating dairy cows require high levels of nutrients to meet their needs for milk production. During early lactation, insulin resistance is one mechanism dairy cows use to repartition glucose away from skeletal muscle and adipose tissue and toward the mammary gland to synthesize milk and milk components (Bauman and Currie, 1980; Aschenbach et al., 2010). The failure of cows to meet their glucose demands for lactation may lead to impaired immune response and increased risk of disease that may affect milk production and profitability (Ingvartsen and Moyes, 2013).

Dietary supplementation with $\mathrm{Cr}$ appears to enhance glucose use by improving insulin sensitivity and glucose metabolism in growing heifers and periparturient cows (Hayirli et al., 2001; Sumner et al., 2007; Spears et al., 2012). Studies evaluating the effect of Cr supplementation on immune response have focused mainly on lymphocyte and neutrophil response. Chromium supplementation enhanced antibody production and mononuclear cell proliferation (Burton et al., 1993). For neutrophils, Cr supplementation did not affect phagocytic activity (Chang et al., 1996), but it did influence the expression of pro-inflammatory genes (Yuan et al., 2014). However, no studies have examined how dietary Cr supplementation alters macrophage response.

Macrophages play a critical role in the innate immune response; they are the first immune cells to encounter pathogens and can lead to an orchestrated innateadaptive response, as well playing a role in metabolism 
and homeostasis (Murray and Wynn, 2011; Italiani and Boraschi, 2014). The M1 phenotype is linked to induction of a pro-inflammatory state, reduction of fatty acid oxidation, and insulin resistance. The M2 phenotype is associated with an anti-inflammatory state, induction of fatty acid oxidation, and insulin sensitivity (Epelman et al., 2014). We hypothesized that dietary supplementation with $\mathrm{Cr}$ propionate would regulate the ability of macrophages to respond to tissue signaling by controlling the pro-inflammatory response. The objective was to characterize the effect of dietary $\mathrm{Cr}$ propionate on the response of polarized macrophages from Holstein cows in mid lactation.

\section{MATERIALS AND METHODS}

\section{Cow Management and Dietary Treatments}

The present experiment was approved in accordance with the regulations and guidelines set forth by the University of Maryland Animal Care and Use Committee.

Twelve primiparous and 16 multiparous ( $\geq 2$ lactations) Holstein cows in mid lactation (143 \pm 37 DIM) were enrolled in this study. Cows had an average milk yield of $37.8 \pm 6.0 \mathrm{~kg}$ and an average BW of $636 \pm 76$ $\mathrm{kg}$. All cows were free from clinical signs of disease, with an average composite milk SCC $\leq 100,000$ cells/ $\mathrm{mL}$ before enrollment. Cows were randomly assigned within parity to receive 1 of 2 dietary treatments: chromium propionate $(\mathbf{C r P})$ or control (CTL; no $\mathrm{CrP}$ ). Cows were individually fed a common lactation TMR once per day $(\sim 0730 \mathrm{~h})$ in tie stalls fitted with mattresses that were bedded with wood shavings. Cows had continuous access to water and were milked twice per day at 0630 and $1600 \mathrm{~h}$.

Feed offered was adjusted daily to achieve 5 to $10 \%$ orts. Orts were collected and weighed daily. The TMR was formulated to meet NRC (2001) requirements for lactating dairy cows (Table 1). During the first week of enrollment (i.e., the adjustment period), cows were fed the common lactation TMR, top-dressed with $200 \mathrm{~g}$ of ground corn. After the adjustment period, cows were fed the same TMR top-dressed with $200 \mathrm{~g}$ of ground corn for $35 \mathrm{~d}$, with $\mathrm{CrP}$ ( $8 \mathrm{mg}$ of $\mathrm{Cr} /$ cow per day) or without $\mathrm{CrP}$ (CTL). The duration of feeding was similar to those of other studies that investigated $\mathrm{Cr}$ supplementation in cows in early lactation (VargasRodriguez et al., 2014; Yuan et al., 2014). Chromium was provided in the form of $20 \mathrm{~g} / \mathrm{d}$ of KemTRACE chromium propionate $0.04 \%$ (Kemin Industries Inc., Des Moines, IA). Forages were collected once a week and analyzed for DM to adjust the as-fed TMR to
Table 1. Ingredients and chemical composition of basal diet fed to Holstein cows in mid lactation

\begin{tabular}{lc}
\hline Item & Value \\
\hline Ingredient, \% of DM & \\
Corn silage & 37.79 \\
Alfalfa hay & 10.44 \\
Sorghum sudangrass haylage & 10.02 \\
Ground corn & 17.64 \\
Soybean meal, 48\% & 12.76 \\
Soy-plus ${ }^{1}$ & 1.51 \\
Wheat middlings & 1.34 \\
Corn gluten meal, $60 \%$ & 0.32 \\
Megalac ${ }^{2}$ & 0.49 \\
Premix & 7.70 \\
Nutrient composition & \\
NE, Mcal/kg & 1.60 \\
CP, \% of DM & 15.27 \\
NDF, \% of DM & 34.53 \\
ADF, \% of DM & 22.43 \\
Ether extract, \% of DM & 2.60 \\
Ca, \% of DM & 0.88 \\
P, \% of DM & 0.46 \\
DCAD, mEq/kg of DM & 282 \\
\hline
\end{tabular}

${ }^{1}$ West Central (Ralston, IA).

${ }^{2}$ Church and Dwight Co. Inc. (Princeton, NJ).

${ }^{3}$ Contained (DM basis) $0.46 \%$ limestone, $0.17 \%$ Biophos (IMCAgrico, Bannockburn, IL), 0.04\% magnesium sulfate, $0.06 \%$ magnesium oxide, $0.25 \%$ sodium bicarbonate, $0.06 \%$ dynamite (Mosaic Co., Plymouth, MN), $0.25 \%$ salt-white, $0.12 \%$ Yeast XP (Diamond V Inc., Cedar Rapids, IA), 0.01\% TM-433 (Southern States Cooperative Inc., Richmond, VA), $0.01 \%$ 4-plex (Southern States Cooperative Inc.) $0.01 \%$ ADE mix $(5,454,545 \mathrm{IU} / \mathrm{kg}$ of vitamin A, $1,818,182 \mathrm{IU} / \mathrm{kg}$ of vitamin $\mathrm{D}, 9,091 \mathrm{IU} / \mathrm{kg}$ of vitamin $\mathrm{E}), 0.01 \%$ vitamin $\mathrm{E}(56,818 \mathrm{IU} / \mathrm{kg})$, $0.03 \%$ selenium (0.06\% selenium), $0.10 \%$ Omnigen-AF (Prince Agri Products Inc., Quincy IL), 0.03\% Rumensin (Elanco, Greenfield, IN).

maintain the formulated DM ratio of forage to concentrate. Samples of TMR were collected once per week and composited in 2 periods for nutritional analysis at a commercial laboratory (Cumberland Valley Analytical Services, Hagerstown, MD). The laboratory performed analysis of $\mathrm{N}, \mathrm{ADF}$, and minerals as described by AOAC International (2000); NDF as described by Van Soest et al. (1991); and ether extract as described by AOAC International (2006).

At d 0, 17, and 35 of feeding, jugular blood $(\sim 200$ $\mathrm{mL}$ ) was collected from each cow. Blood was drained via sterile IV catheters (Neogen Co., Lansing, MI) and collected into $15 \mathrm{~mL}$ sterile tubes containing $10 \%$ acidcitrate dextrose (ACD; Sigma-Aldrich Co., St. Louis, MO). Tubes were gently inverted $\sim 15$ times and placed on ice. Blood samples were processed within $2 \mathrm{~h}$ after collection. In addition, jugular blood $(\sim 10 \mathrm{~mL})$ was collected with $\mathrm{K}_{2}$ EDTA (Thermo Fisher Scientific Inc., Waltham, MA) for whole blood cell composition using a ProCyte Dx hematology analyzer (Idexx Laboratories Inc., Westbrook, ME). Tubes containing $\mathrm{K}_{2}$ EDTA were centrifuged at $2,000 \times g$ for $15 \mathrm{~min}$ at $4^{\circ} \mathrm{C}$, and plasma was frozen at $-20^{\circ} \mathrm{C}$ until further analysis. 


\section{Monocyte-Derived Macrophage Isolation, Culture, and Polarization}

The procedure for monocyte-derived macrophage (MDM) isolation was modified from previous publications (Walter and Morck, 2002; Martinez, 2012). Whole blood containing $10 \%$ ACD $(\sim 200 \mathrm{~mL})$ was centrifuged at $1,000 \times g$ for $25 \mathrm{~min}$. The buffy coat was transferred and diluted (1:3) with ACD-PBS (2.5 $\mathrm{m} M$ ACD in $1 \times$ PBS, pH 7.4, Sigma-Aldrich Co.) and carefully layered on Ficoll-paque Plus 1.077 density (GE Healthcare, Waukesha, WI) at a ratio of $6 \mathrm{~mL}$ of Ficoll-paque to 8 $\mathrm{mL}$ of diluted buffy coat, and immediately centrifuged at $700 \times g$ for $40 \mathrm{~min}$. After centrifugation, the opaque interphase containing mononuclear cells was transferred to a sterile tube and diluted (1:4) with ACD-PBS, followed by centrifugation at $500 \times g$ for $10 \mathrm{~min}$. For lysis of red blood cells, the cell pellet was resuspended in 5 $\mathrm{mL}$ of ACK-lysing buffer (Gibco, Thermo Fisher Scientific Inc.), isotonicity was restored after 3 min with $1 \times$ PBS, and then it was centrifuged at $250 \times g$ for 5 min. Cells were washed 2 more times with ACD-PBS at 250 $\times g$ for 10 min and then at $400 \times g$ for 5 min to remove remnant platelets. Pellets containing mononuclear cells were resuspended with RPMI 1640 medium (SigmaAldrich Co.) to reach a cell concentration of $5 \times 10^{6}$ to $10 \times 10^{6}$ cells $/ \mathrm{mL}$, quantified using a TC-20 automated cell counter (Bio-Rad Laboratories Inc., Hercules, CA).

Mononuclear cells were plated $(3 \mathrm{~mL}$ per well $)$ in 6-well plates (Falcon 353046, Becton Dickinson Labware, Franklin Lakes, NJ) and incubated for $2 \mathrm{~h}$ at $37^{\circ} \mathrm{C}$ and $5 \% \mathrm{CO}_{2}$ to allow monocytes to adhere to the bottom of the wells. After this, non-adherent cells were removed with the medium using sterile pipettes. Adhered monocytes were washed 4 times with $4 \mathrm{~mL}$ of $1 \times \operatorname{PBS}\left(37^{\circ} \mathrm{C}\right)$ per well. Monocytes were detached with Accutase solution $\left(1 \mathrm{~mL}\right.$ per well and incubated at $37^{\circ} \mathrm{C}$ for $10 \mathrm{~min}$; Global Cell Solutions, Charlottesville, VA), and then transferred to a sterile tube and centrifuged at $500 \times g$ for $10 \mathrm{~min}$. The monocyte pellet was reconstituted with modified RPMI medium (90\% RPMI 1640 medium, $10 \%$ fetal bovine serum, $2 \%$ of 10,000 $\mathrm{U}$ of penicillin $/ 10 \mathrm{mg}$ of streptomycin $/ \mathrm{mL}$, and $0.03 \%$ glutamine; Sigma-Aldrich Co.) to a final concentration of $4 \times 10^{5}$ cells $/ \mathrm{mL}$.

Monocytes $\left(4 \times 10^{5}\right.$ cells/well, $94 \%$ viability, measured by exclusion method with trypan blue $0.1 \%$, Bio-Rad Laboratories Inc.) were seeded in 2 plates of 24 wells (Falcon 353047, Becton Dickinson Labware); 4 wells per sample were added to 1 plate (for harvest of MDM-M0 and measure of viability) and 6 wells per sample in the other plate (for harvest of MDM-M1 and MDM-M2). After $7 \mathrm{~d}$ of culture at $37^{\circ} \mathrm{C}$ and $5 \% \mathrm{CO}_{2}$, the spent medium was carefully removed, aliquoted, and stored at $-80^{\circ} \mathrm{C}$ until analysis of MDM-M0. The viability of MDM after $7 \mathrm{~d}$ was $87 \%$ and did not differ by treatment. The MDM for harvest of the M0 phenotype were lysed directly in each well with $200 \mu \mathrm{L}$ of TRIzol reagent (Thermo Fisher Scientific Inc.) and immediately stored at $-80^{\circ} \mathrm{C}$ for RNA extraction. The medium in the plate for the polarized MDM-M1 and MDM-M2 was replaced with modified RPMI medium containing IFN- $\gamma(50 \mu \mathrm{g} / \mathrm{mL})$ or IL-4 $(40 \mu \mathrm{g} / \mathrm{mL})$, respectively, and incubated for $48 \mathrm{~h}$ at $37^{\circ} \mathrm{C}$ and $5 \% \mathrm{CO}_{2}$. Then, media and cells were collected and lysed, respectively, as indicated above for MDM-M0. Gene expression of specific markers for MDM-M1 and MDM-M2 were analyzed to verify the polarization capability of IFN- $\gamma$ and IL-4 for bovine MDM. Results and discussion of genes being differentially regulated between phenotypes are presented in the Supplemental Material (https://doi. org/10.3168/jds.2016-12079).

\section{Analysis of Metabolites and Proteins}

Glucose and Nonesterified Fatty Acid Assays. Commercial kits were used to measure plasma concentrations of glucose (Stanbio Laboratories, Boerne, TX) and nonesterified fatty acids (NEFA; NEFA-HR kit; Wako Diagnostics Inc., Richmond, VA). Analyses were performed as detailed elsewhere (Garcia et al., 2015). For glucose, the intra- and interassay CV were 2.7 and $5.6 \%$, respectively. For NEFA, the intra- and interassay $\mathrm{CV}$ were 1.3 and $0.5 \%$, respectively.

Insulin Assay. Plasma samples were analyzed by a direct sandwich technique of 2 monoclonal antibodies specific for bovine insulin, following the manufacturer's protocol (Mercodia Inc., Uppsala, Sweden; https:// www.mercodia.se/mercodia-bovine-insulin-elisa). Undiluted samples were run in duplicate. The intra- and inter-assay CV were 1.5 and $4.3 \%$, respectively.

Revised Quantitative Insulin Sensitivity Check Index. Insulin sensitivity was calculated by estimating the revised quantitative insulin sensitivity check index (RQUICKI) value. Plasma concentrations of glucose, NEFA, and insulin were used to calculate the RQUICKI value: $1 /[\log ($ glucose, $\mathrm{mg} / \mathrm{dL})+\log (\mathrm{NEFA}$, $\mathrm{mmol} / \mathrm{L})+\log ($ insulin, $\mu \mathrm{U} / \mathrm{L})]$, as presented elsewhere to identify lactating cows with disturbed insulin function (Holtenius and Holtenius, 2007).

Tumor Necrosis Factor- $\alpha$ Assay. Spent media were analyzed for concentrations of tumor necrosis factor (TNF)- $\alpha$ using a bovine-TNF- $\alpha$ commercial kit (Vet Sets Elisa Development Kit; Kingfisher Biotech Inc., St. Paul, MN; http://www.kingfisherbiotech.com/ product/VS0285B-002/BOVINE_TNF-ALPHA_ELISA_VETSET?referrer=TNF-alpha_18), following the manufacturer's protocol with modifications. Standards 
were prepared with RPMI-modified buffer (SigmaAldrich Co.). Undiluted samples were run in duplicate where samples for each MDM phenotype (i.e., M0, M1, and M2), including the 3 sampling points for each cow, were run in a given plate. If the absorbance was lower than the blank, a zero value was assigned. The intraand interassay CV were 4.5 and $12.5 \%$, respectively.

Nitric Oxide Assay. Spent media were analyzed for concentrations of nitric oxide using the Griess Reagent System (Promega, Madison, WI; https://www. promega.com/resources/protocols/technical-bulletins/0/griess-reagent-system-protocol/) following the manufacturer's protocol. Standards were prepared with modified RPMI medium. Undiluted samples were run in duplicate; samples for each MDM phenotype (i.e., M0, M1, and M2) for each cow were run in a given plate. If absorbance was not detected, a zero value was assigned. The intra- and inter-assay CV were 2.8 and $6.3 \%$, respectively.

\section{RNA Isolation, cDNA Synthesis, and Quantitative Reverse Transcription PCR (qPCR)}

A subset of 5 cows per treatment $\times$ parity $(2 \times 2)$ for each MDM phenotype (M0, M1, and M2) and at d 17 and 35 of Cr supplementation were used for downstream quantitative PCR (qPCR) analysis ( $\mathrm{n}=120$ total samples). The number of biological replicates per treatment $\times$ parity were selected based on previous studies measuring the inflammatory and metabolic response of MDM types via qPCR in rodents (Tavakoli et al., 2013) and dairy cattle (Eger et al., 2016). Specific details for total RNA isolation and quality evaluation, cDNA synthesis, primer selection and efficiency evaluation, and $\mathrm{qPCR}$ analysis are presented in the Supplemental Material (https://doi.org/10.3168/jds.2016-12079). The purity of the extracted RNA was calculated using an absorbance ratio of 260/280, measured using a NanoVue Plus (GE Healthcare, Piscataway, NJ), and had a median value of 1.7. The integrity of the RNA was measured using the RNA quality indicator number and an Experion bioanalyzer (Bio-Rad Laboratories Inc.), and had a median value of 9.8. Primer sequences and accession numbers are presented in Supplemental Table S1 (https://doi.org/10.3168/jds.2016-12079). Primer and $\mathrm{qPCR}$ validation detailing the slope, intercept, $\mathrm{R}^{2}$, and efficiency of the dilution curve, as well as the range of quantification cycle $(\mathbf{C q})$ values and the median for each gene across all samples, can be found in Supplemental Table S2 (https://doi.org/10.3168/ jds.2016-12079). Reference genes $A C T B$ and B2M were determined as the most stable genes based on their low standard deviation and high coefficient of correlation among 4 genes (ACTB, B2M, GAPDH, and HPRT1) and tested for their stability as reference genes in MDM, using the Excel-based tool BestKeeper (Pfaffl et al., 2004). The qPCR results were analyzed using the Pfaffl method (Pfaffl, 2001). Briefly, the Cq value of each gene was adjusted for its own efficiency of amplification $\left(\mathrm{E}^{-\mathrm{Cq}}\right)$ and then normalized with the adjusted $\mathrm{Cq}$ of the reference genes to calculate the $\mathrm{E}^{-\Delta \mathrm{Cq}}$ by dividing the $\mathrm{E}^{-\mathrm{Cq}}$ of a target gene $\left(\mathrm{E}^{-\mathrm{Cq} \text { target }}\right)$ by the $\mathrm{E}^{-\mathrm{Cq}}$ of the geometric mean of the references $\left(\mathrm{E}^{- \text {Cqreferences }}\right)$. The $\log _{10}$ of the $\mathrm{E}^{-\Delta \mathrm{Cq}}$ was subjected to statistical analysis.

\section{Statistical Analysis}

A mixed linear regression with the PROC MIXED procedure of SAS (SAS/STAT version 9.2; SAS Institute Inc., Cary, NC) was used for statistical analysis. The data were tested for normality and the presence of outliers, and adjusted accordingly. Briefly, log-transformation was performed for monocyte and eosinophil number and lymphocyte percentage; red blood cell number (squared) and the inverse value for platelet number were used. For parameters in blood and spent media, class variables included cow, parity, treatment, and time. The randomized complete block design model included the respective covariate, the fixed effects of treatment and parity, and the random effect of cow nested within parity and treatment, as detailed in the following model,

$$
\mathrm{Y}_{\mathrm{ijk}}=\operatorname{Cov}+\mu+\mathrm{T}_{\mathrm{i}}+\mathrm{P}_{\mathrm{j}}+\varepsilon_{\mathrm{ij}},
$$

where $Y_{\mathrm{ijk}}$ was the dependent variable; Cov was the covariate value (i.e., average of first wk or $\mathrm{d}$ of first measure); $\mu$ was the overall mean; $\mathrm{T}_{\mathrm{i}}$ was the fixed effect of treatment i (CTL or $\mathrm{CrP}) ; \mathrm{P}_{\mathrm{j}}$ was the fixed effect of parity level $\mathrm{j}$ (primiparous or multiparous), and $\varepsilon_{\mathrm{ij}}$ was the residual error.

For gene expression data only, the class variables included cow, parity, treatment, and time. The randomized complete block design model included the fixed effect of treatment, parity, day, and the random effect of cow nested within parity and treatment, as detailed in the following model,

$$
\begin{gathered}
\mathrm{Y}_{\mathrm{ijk}}=\mu+\mathrm{T}_{\mathrm{i}}+\mathrm{P}_{\mathrm{j}}+\mathrm{D}_{\mathrm{k}}+\mathrm{TP}_{\mathrm{ij}}+\mathrm{TD}_{\mathrm{ik}} \\
+\mathrm{TPD}_{\mathrm{ijk}}+\varepsilon_{\mathrm{ijk}},
\end{gathered}
$$

where $Y_{i j k}$ was the dependent variable; $\mu$ was the overall mean; $\mathrm{T}_{\mathrm{i}}$ was the fixed effect of treatment $\mathrm{i}$ (CTL or $\mathrm{CrP}$ ); $\mathrm{P}_{\mathrm{j}}$ was the fixed effect of parity level $\mathrm{j}$ (primiparous or multiparous); $D_{k}$ was the fixed effect of time 
Table 2. Hormones and metabolites in plasma and index of insulin sensitivity of primiparous and multiparous Holstein cows in mid lactation fed either Cr propionate $(\mathrm{CrP})$ or control (CTL) for $35 \mathrm{~d}^{1}$

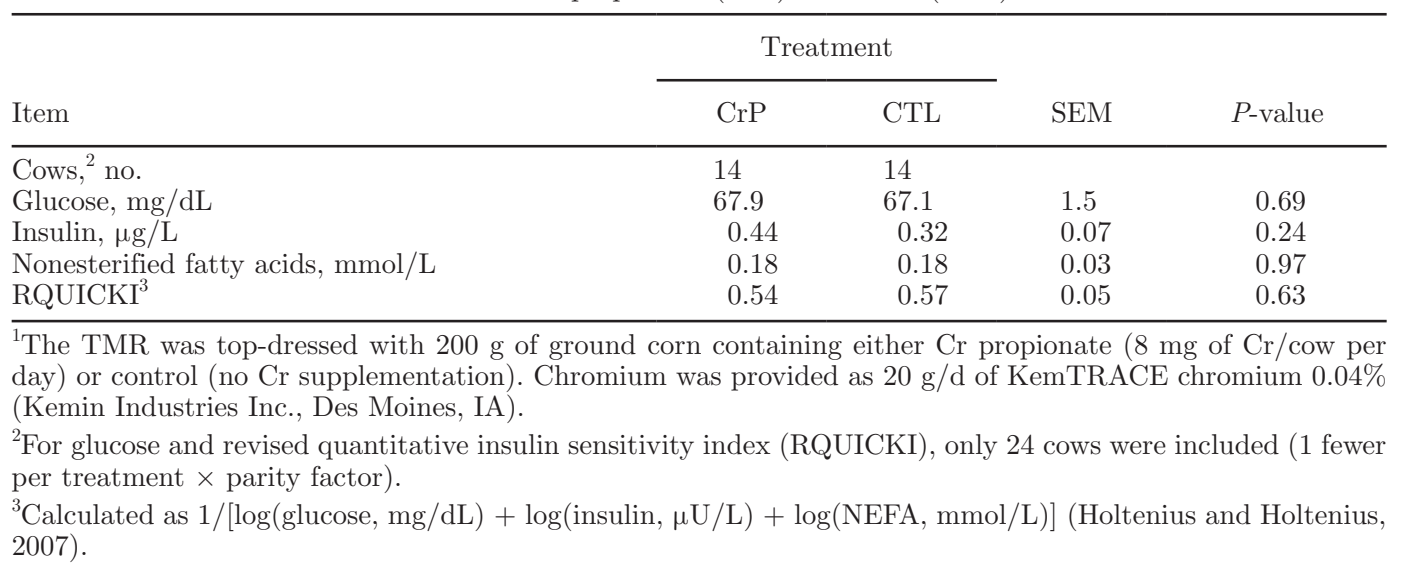

(d) at level $\mathrm{k}(1,2,3, \ldots ., \mathrm{n})$; $\mathrm{TP}_{\mathrm{ij}}$ was the interaction of treatment $\times$ parity; $\mathrm{TD}_{\mathrm{ik}}$ was the interaction of treatment $\times$ time, $\mathrm{TPD}_{\mathrm{ijk}}$ was the 3 -way interaction of treatment $\times$ parity $\times$ time, and $\varepsilon_{\mathrm{ijk}}$ was the residual error. The 3 -way interaction of treatment $\times$ parity $\times$ day was removed from the model when $P>0.25$.

Repeated measures were tested to determine the structure of best fit as indicated by the smallest Schwartz Bayesian information criteria. For all models, degrees of freedom were estimated using the KenwardRoger specification in the model statement. The results are presented as least squares means (LSM) and the largest standard error of the mean, where applicable. Statistical differences were declared as significant if $P$ $\leq 0.05$ and a tendency if $0.05<P \leq 0.10$ for main effects or $0.05<P \leq 0.15$ for interactions (Robinson and Wainer, 2002).

For gene expression data with significant interactions, separation of LSM was performed using the PDIFF statement of SAS (SAS Institute Inc.). For gene expression data, fold-change $(\mathbf{F C})$ values were calculated according to Pfaffl (2001). Briefly, the LSM $\left(\log 10\right.$ of $\left.\mathrm{E}^{-\Delta \mathrm{Cq}}\right)$ of a factor of interest (e.g., $\left.\mathrm{CrP}\right)$ was subtracted from the LSM $\left(\log 10\right.$ of $\left.\mathrm{E}^{-\Delta \mathrm{Cq}}\right)$ of another referential factor (e.g., CTL) and transformed back to give linearized $\mathrm{FC}$ values.

\section{RESULTS}

\section{Blood and Spent Media}

Plasma concentrations of glucose, insulin, and NEFA, as well as the RQUICKI index, were unaltered by the main effect of treatment (Table 2). Neither the whole blood cell population nor a specific proportion of leukocytes was affected by the main effect of treatment (Table 3). However, we did observe a trend $(P=0.09)$ for fewer neutrophils in cows fed $\mathrm{CrP}$ than in cows fed CTL for $35 \mathrm{~d}$. Concentrations of glucose, TNF- $\alpha$, and nitrate in spent media of any MDM type were not affected by the main effect of treatment (Table 4).

\section{Monocyte-Derived Macrophage Gene Expression}

Dietary chromium had minimal effects on the expression of genes involved in nutrient metabolism and inflammatory response for MDM-M0 (Table 5). Feeding $\mathrm{CrP}$ increased the expression of $I G F I$, coding for insulin-like growth factor-I $(\mathrm{FC}=1.66, P=0.03)$, but treatment or its interactions did not affect the expression of genes coding for the insulin receptor (INSR), glucose transporters (SLC2A1,SLC2A3, and SLC2A5), or genes related to inflammatory response.

Expression of genes in polarized MDM-M1were not affected by the main effect of treatment, but genes involved in glucose uptake were affected by the 3 -way interaction of treatment $\times$ parity $\times$ time $(P \leq 0.13$, Figure 1). The expression of INSR (Figure 1A) on a given day was not affected by treatment or its interaction with parity. With regard to the effect of time, primiparous cows fed CTL had increased expression of INSR at $\mathrm{d} 35$ than at $\mathrm{d} 17(\mathrm{FC}=3.38$, treatment $\times$ parity $\times$ time, $P=0.06$ ). At d 17 , expression of $S L$ C2A3 (Figure 1B) was downregulated for primiparous cows compared with multiparous cows. For multiparous cows, SLC2A3 was upregulated at d 35 compared with $\mathrm{d} 17$ (treatment $\times$ parity $\times$ time, $P=0.01$ ). For SLC2A5 (Figure 1C), primiparous cows experienced an increase in expression compared with multiparous cows fed either treatment at d $17(\mathrm{FC}=9.8$, treatment $\times$ parity $\times$ time, $P=0.13$ ), but this effect was not observed at $35 \mathrm{~d}$. For multiparous cows fed CTL, the expression of SLC2A5 increased at d 35 compared with $\mathrm{d}$ 17. The expression of genes coding for different 
Table 3. Blood cell number and proportion from primiparous and multiparous Holstein cows in mid lactation fed either Cr propionate (CrP) or control (CTL) for $35 \mathrm{~d}^{1}$

\begin{tabular}{lcccc}
\hline & \multicolumn{2}{c}{ Treatment } & & \\
\cline { 2 - 3 } Item & CrP & CTL & SEM & P-value \\
\hline Cows, ${ }^{2}$ no. & 10 & 10 & & \\
Red blood cells, $\times 10^{12} / \mathrm{L}$ & 6.49 & 6.63 & 0.15 & 0.51 \\
Platelets, $\times 10^{9} / \mathrm{L}$ & 384.9 & 383.1 & 16.9 & 0.94 \\
Leukocytes, $\times 10^{9} / \mathrm{L}$ & 9.46 & 9.87 & 16.9 & 0.39 \\
Lymphocytes, $\times 10^{9} / \mathrm{L}$ & 4.88 & 4.58 & 0.19 & 0.24 \\
Neutrophils, $\times 10^{9} / \mathrm{L}$ & 3.19 & 3.81 & 0.25 & 0.09 \\
Monocytes, $\times 10^{9} / \mathrm{L}$ & 0.98 & 1.00 & 0.08 & 0.89 \\
Eosinophils, $\times 10^{9} / \mathrm{L}$ & 0.19 & 0.25 & 0.03 & 0.29 \\
\% of Leukocytes & & & & \\
Lymphocytes & 53.1 & 49.6 & 1.3 & 0.21 \\
Neutrophils & 32.4 & 37.0 & 1.9 & 0.11 \\
Monocytes & 10.7 & 10.0 & 1.0 & 0.61 \\
Eosinophils & 1.98 & 2.33 & 0.22 & 0.45 \\
\hline
\end{tabular}

${ }^{1}$ The TMR was top-dressed with $200 \mathrm{~g}$ of ground corn containing either $\mathrm{Cr}$ propionate $(8 \mathrm{mg}$ of $\mathrm{Cr} /$ cow per day) or control (no Cr supplementation). Chromium was provided as $20 \mathrm{~g} / \mathrm{d}$ of KemTRACE chromium $0.04 \%$ (Kemin Industries Inc., Des Moines, IA).

${ }^{2}$ Cows enrolled in wk 1 and 2 of the second period were not included because of missing values for covariate day.

inflammatory markers in MDM-M1 were not affected by treatment or its interactions.

For MDM-M2, neither treatment nor the interaction of treatment $\times$ parity altered genes associated with nutrient metabolism (Table 5). With regard to the immune response, $\mathrm{CrP}$-fed cows experienced a trend for a greater expression of $C X C L 11$, coding for an interferon-inducible chemokine $(\mathrm{FC}=2.14, P=0.07)$.
Expression of SLC2A3 tended to increase (treatment $\times$ time, $P=0.06)$ with $\mathrm{CrP}$ compared with CTL at d $17(\mathrm{FC}=2.11)$ but did not differ at $\mathrm{d} 35$. For the 3 -way interaction (treatment $\times$ parity $\times$ time), IGFI expression (Figure 2A) increased in primiparous cows fed $\mathrm{CrP}$ compared with primiparous or multiparous cows fed either treatment $(\mathrm{FC}=3.24$, treatment $\times$ parity $\times$ time, $P=0.05$ ), whereas SLC2A5 (Figure $2 \mathrm{~B}$ )

Table 4. Glucose, tumor necrosis factor (TNF)- $\alpha$, and nitrate concentration in spent media of monocytederived macrophages $(\mathrm{MDM})^{1}$ from Holstein cows in mid lactation fed $\mathrm{Cr}$ propionate $(\mathrm{CrP})$ or control (CTL) for $35 \mathrm{~d}^{2}$

\begin{tabular}{lrrrr}
\hline & \multicolumn{2}{c}{ Treatment } & & \\
\cline { 2 - 3 } Item & CrP & CTL & SEM & $P$-value \\
\hline Cows, no. & 13 & 13 & & \\
MDM-M0 & & & & \\
Glucose, mg/dL & 159.2 & 156.2 & 3.4 & 0.54 \\
TNF- $\alpha$, ng/L & 17.5 & 20.5 & 3.1 & 0.52 \\
Nitrate, nM & 530.6 & 707.7 & 143.2 & 0.40 \\
MDM-M1 & & & & 0.22 \\
Glucose, mg/dL & 173.7 & 170.3 & 1.9 & 0.99 \\
TNF- $\alpha$, ng/L & 33.3 & 33.2 & 8.8 & 0.66 \\
Nitrate, nM & 393.7 & 451.3 & 92.3 & 0.42 \\
MDM-M2 & & & & 0.40 \\
Glucose, mg/dL & 173.3 & 175.4 & 1.8 & 0.52 \\
TNF- $\alpha$, ng/L & 15.6 & 10.2 & 4.3 & 75.7 \\
Nitrate, $\mathrm{nM}$ & 280.3 & 350.1 & & \\
\hline
\end{tabular}

${ }^{1}$ MDM-M0 were cultured for $7 \mathrm{~d}$ in modified RPMI medium (90\% RPMI 1640 medium, $10 \%$ fetal bovine serum, $2 \%$ of $10,000 \mathrm{U}$ of penicillin/10 mg of streptomycin/mL, and $0.03 \%$ glutamine; Sigma-Aldrich Co., St. Louis, MO) without cytokines. MDM-M1 were obtained from stimulation of MDM-M0 with IL-4 (40 ng/mL, $1 \mathrm{~mL}$ of total medium culture) for $48 \mathrm{~h}$. MDM-M2 were obtained from stimulation of MDM-M0 with IFN- $\gamma$ (50 ng/ $\mathrm{mL}, 1 \mathrm{~mL}$ of total medium culture) for $48 \mathrm{~h}$.

${ }^{2}$ The TMR was top-dressed with $200 \mathrm{~g}$ of ground corn containing either $\mathrm{Cr}$ propionate $(8 \mathrm{mg}$ of $\mathrm{Cr} / \mathrm{cow}$ per day) or control (no Cr supplementation). Chromium was provided as $20 \mathrm{~g} / \mathrm{d}$ of KemTRACE chromium $0.04 \%$ (Kemin Industries Inc., Des Moines, IA). 
Table 5. Relative RNA expression $\left(\log _{10}\right.$ of $\left.\mathrm{E}^{-\Delta \mathrm{Cq}}\right)$ of genes involved in nutrient metabolism and inflammatory response in monocyte-derived macrophages (MDM) ${ }^{1}$ from primiparous (Prim) and multiparous (Mult) Holstein cows in mid lactation fed either Cr propionate (CrP) or control (CTL) for $35 \mathrm{~d}^{2}$

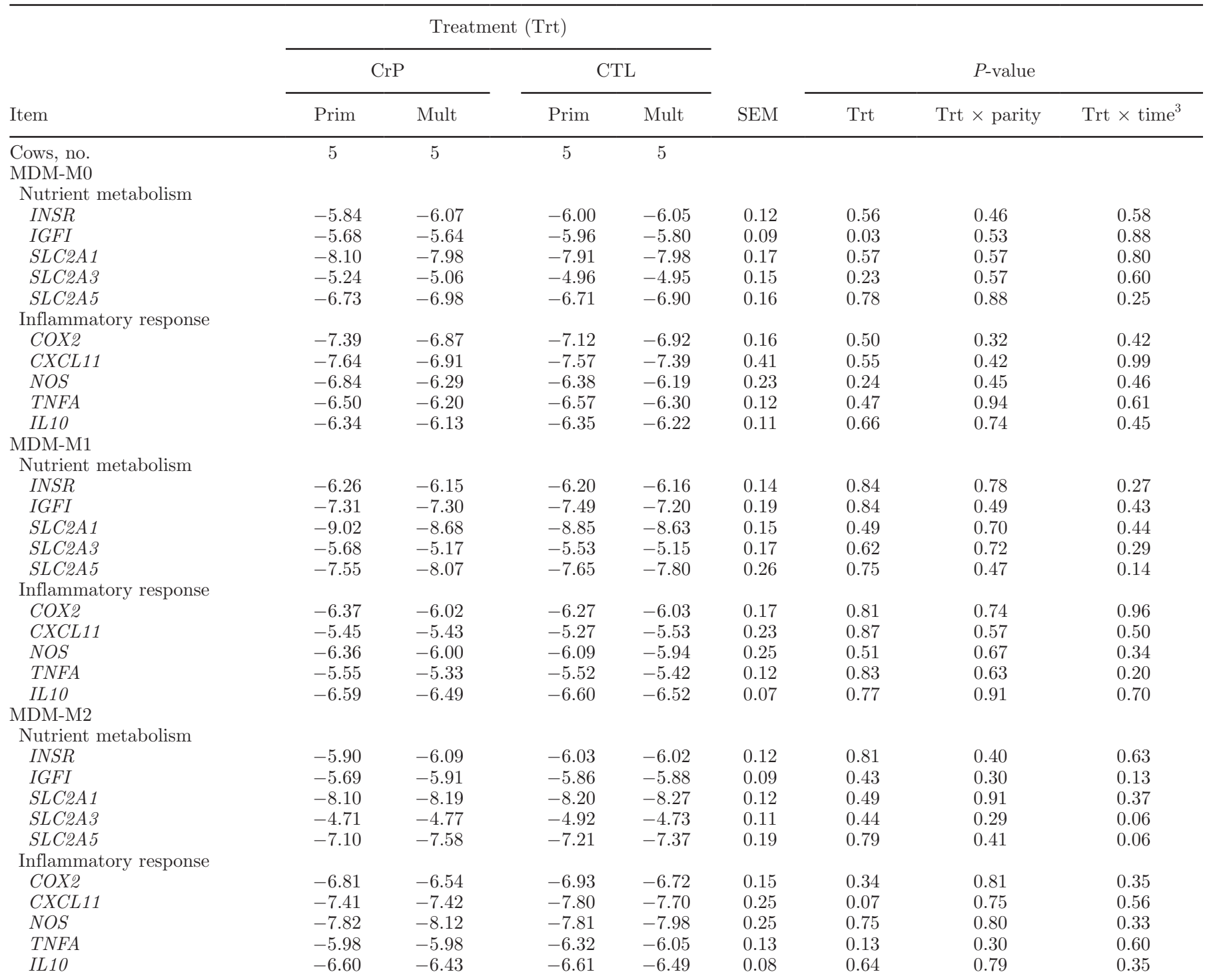

${ }^{1}$ MDM-M0 were cultured for $7 \mathrm{~d}$ in modified RPMI medium (90\% RPMI 1640 medium, $10 \%$ fetal bovine serum, $2 \%$ of 10,000 U of penicillin/10 $\mathrm{mg}$ of streptomycin $/ \mathrm{mL}$, and $0.03 \%$ glutamine; Sigma-Aldrich Co., St. Louis, MO) without cytokines. MDM-M1 were obtained from stimulation of MDM-M0 with IL-4 (40 ng/mL, $1 \mathrm{~mL}$ of total medium culture) for $48 \mathrm{~h}$. MDM-M2 were obtained from stimulation of MDM-M0 with IFN- $\gamma$ $(50 \mathrm{ng} / \mathrm{mL}, 1 \mathrm{~mL}$ of total medium culture) for $48 \mathrm{~h}$.

${ }^{2}$ The TMR was top-dressed with $200 \mathrm{~g}$ of ground corn containing either Cr propionate ( $8 \mathrm{mg}$ of $\mathrm{Cr} /$ cow per day) or control (no Cr supplementation). Chromium was provided as $20 \mathrm{~g} / \mathrm{d}$ of KemTRACE chromium 0.04\% (Kemin Industries Inc., Des Moines, IA).

${ }^{3}$ Time corresponds to samples at 0 (covariate), 17, and $35 \mathrm{~d}$ of $\mathrm{Cr}$ propionate supplementation.

expression increased in primiparous cows compared with multiparous cows fed either treatment $(\mathrm{FC}=8.44$, treatment $\times$ parity $\times$ time, $P=0.07)$.

\section{DISCUSSION}

The effect of $\mathrm{CrP}$ supplementation on the bovine macrophage response has not been evaluated. Previous studies have shown that $\mathrm{CrP}$ supplementation alters the influx of neutrophils into peripheral tissues; $\mathrm{CrP}$ supplementation may have positive effects on uterine health for cows during the periparturient period (Yasui et al., 2014) and may partly explain the trend for lower neutrophils for cows fed $\mathrm{CrP}$ in this study. Coupled with the benefits of CrP supplementation for glucose use and insulin sensitivity (Hayirli et al., 2001; Sumner 


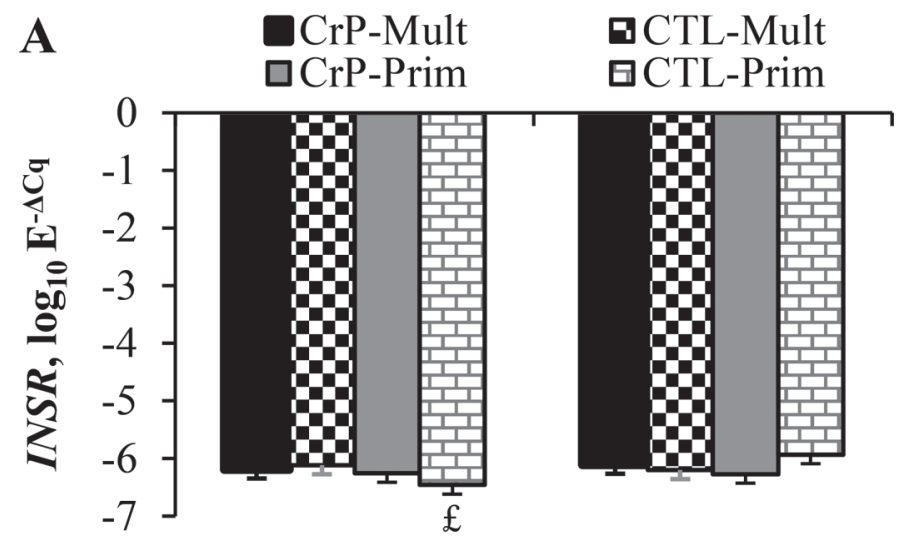

17

35

\section{B}

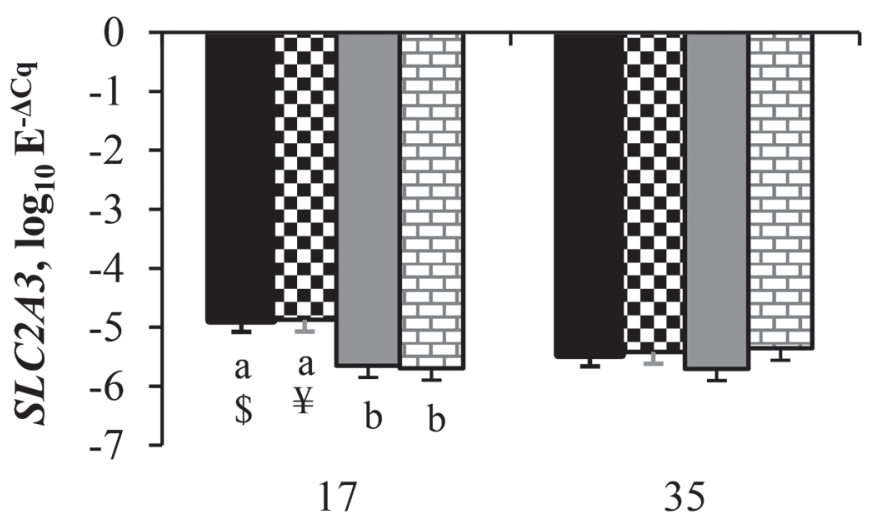

C

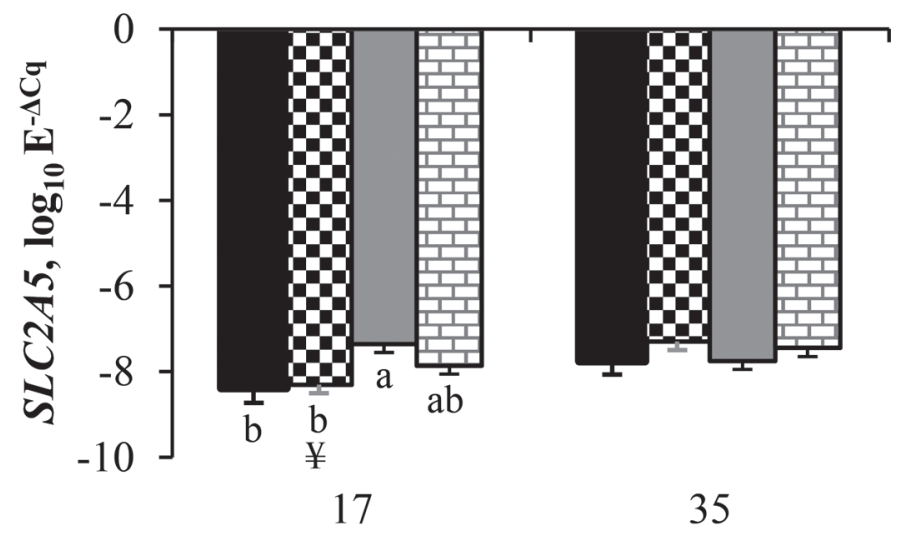

Days in treatment

Figure 1. Relative expression of (A) INSR (treatment $\times$ parity $\times$ time, $P=0.06$ ), (B) SLC2A3 (treatment $\times$ parity $\times$ time, $P=0.01$ ), and $(\mathrm{C})$ SLC2A5 (treatment $\times$ parity $\times$ time, $P=0.13$ ) in monocyte-derived macrophages type 1 derived from primiparous (Prim) and multiparous (Mult) Holstein cows in mid lactation fed either $\mathrm{Cr}$ propionate $(\mathrm{CrP})$ or control (CTL, no Cr supplementation) for $35 \mathrm{~d}$. Within day, pairwise differences are represented with different lowercase $(P<0.05)$ letters. Pairwise differences $(P<0.05)$ between days are represented as $\$$ (CrP-Mult), £ (CTL-Prim), and $¥$ (CTL-Mult). Error bars represent SEM.

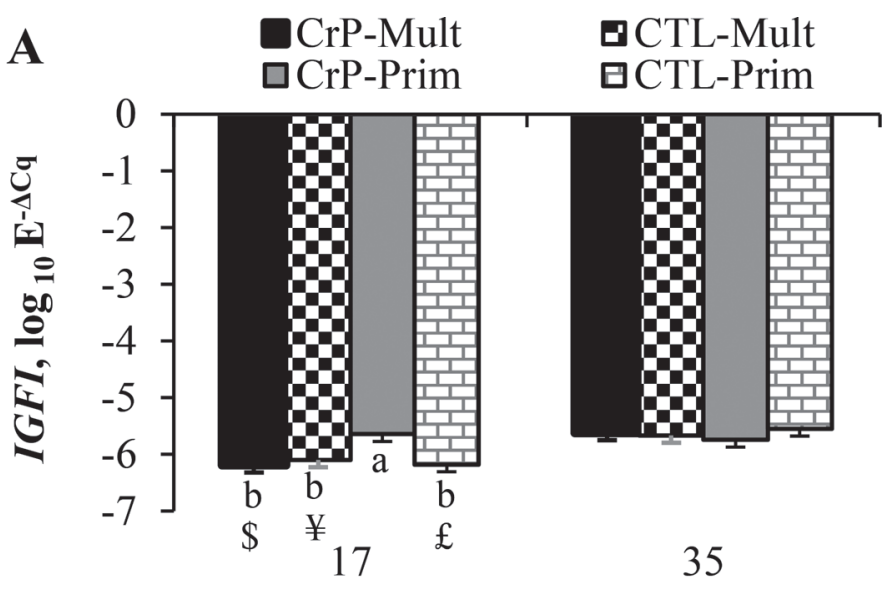

B

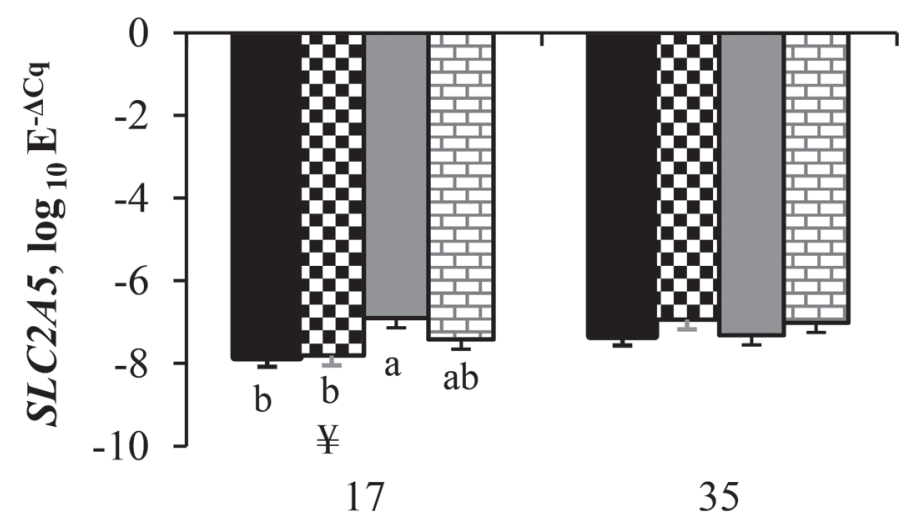

Days in treatment

Figure 2. Relative expression of (A) IGFI (treatment $\times$ parity $\times$ time, $P=0.05$ ) and (B) SLC2A5 (treatment $\times$ parity $\times$ time, $P=$ $0.07)$ in monocyte-derived macrophages type 2 derived from primiparous (Prim) and multiparous (Mult) Holstein cows in mid lactation fed either $\mathrm{Cr}$ propionate $(\mathrm{CrP})$ or control (CTL, no Cr supplementation) for $35 \mathrm{~d}$. Within day, pairwise differences are represented with different lowercase $(P<0.05)$ letters. Pairwise differences $(P<0.05)$ between days are represented as $\$$ (CrP-Mult), £ (CTL-Prim), and $¥$ (CTLMult). Error bars represent SEM.

et al., 2007; Spears et al., 2012), the current findings suggest that $\mathrm{CrP}$ supplementation may have positive effects on macrophage response in dairy cows. Our data suggest that this response may be more marked for primiparous Holstein cows in mid lactation.

The duration of $\mathrm{Cr}$ supplementation and stage of lactation may partly explain the lack of results from feeding CrP to mid-lactation Holstein dairy cows in this study. The length of $\mathrm{Cr}$ supplementation in the current study was modeled after the studies of others (Vargas-Rodriguez et al., 2014; Yuan et al., 2014) who supplemented CrP to early-lactation cows for $35 \mathrm{~d}$ and observed changes in neutrophil activity. Others have reported that supplementing $\mathrm{CrP}$ to mid-lactation 
cows for $210 \mathrm{~d}$ (Leiva et al., 2015) resulted in a temporary change in serum insulin. Furthermore, for cows during the transition period ( -21 to 35 DIM), CrP supplementation did not change plasma glucose or NEFA, but rates of lipogenesis were greater than for non-supplemented cows in early lactation (McNamara and Valdez, 2005). It appears that the effect of Cr on inflammatory and metabolic response depends on the stage of lactation and length of supplementation. The marginal and conditional changes in gene expression for MDM in the present study may be partly attributable to a combination of stage of lactation and length of supplementation.

Blood cell counts for healthy cows were within expected values for their physiological stage (George et al., 2010). The trend for a decrease in neutrophils that we observed for cows fed $\mathrm{CrP}$ in this study may be partly attributable to a greater influx of neutrophils into peripheral tissues, a reduced pro-inflammatory response during disease, or both, but this warrants future study. When evaluating within parity (data not shown), primiparous cows tended to have greater $(P=$ $0.10)$ monocyte concentrations in blood $\left(1.31 \times 10^{3} /\right.$ $\mu \mathrm{L})$ than multiparous cows $\left(0.85 \times 10^{3} / \mu \mathrm{L}\right)$ fed $\mathrm{CrP}$ for $35 \mathrm{~d}$ during mid lactation. Monocytes serve as a systemic reservoir for replenishment of tissue macrophages (Italiani and Boraschi, 2014). We observed no differences for glucose, TNF- $\alpha$, or nitrate concentration in spent media for any of the MDM measured for this study between cows fed CrP or CTL for $35 \mathrm{~d}$ during mid lactation. However, the higher number of circulating monocytes observed in primiparous cows fed $\mathrm{CrP}$ than in multiparous cows fed $\mathrm{CrP}$ may indicate a reduced uptake of circulating monocytes into peripheral tissues for primiparous cows related to reduced inflammatory condition (Murray et al., 2014). This hypothesis is partly supported by (1) the trend for lower circulating neutrophils for CrP than CTL-fed cows; (2) the tendency for lower production of the inflammatory cytokine TNF- $\alpha$ by MDM-M1 from primiparous cows fed CrP (data not shown, $P=0.12$ ); and (3) the numerically lower (treatment $\times$ parity, $P=0.56$ ) production of nitrate by non-activated MDM (M0) from primiparous compared with multiparous cows fed $\mathrm{CrP}(401 \pm 202$ vs. $820 \pm 189 \mathrm{n} M$, pairwise comparison, $P=0.14$; data not shown). Lower TNF- $\alpha$ production may be beneficial for the host because of association of high TNF- $\alpha$ with inflammation, increased risk of the development of type 2 diabetes mellitus (Fernández-Real and Pickup, 2008; Calle and Fernandez, 2012), and the link between obesity and low-grade inflammation in cattle (Bradford et al., 2015). Monocyte-derived macrophages have unique characteristics, such as the detection of invading microorganisms, integrating immune balance, and energy homeostasis (Lee et al., 2014). Although major differences were expected, the effects of $\mathrm{CrP}$ on the response of MDM of any phenotype (M0, M1, and M2) regarding the inflammatory and metabolic response were not observed for Holstein cows in mid lactation.

Among the genes involved primarily in nutrient metabolism, IGFI was expressed 1.6 times more in MDM-M0 CrP-fed cows than CTL-fed cows. Increased expression of IGFI has been associated with macrophage differentiation from primitive progenitors (M0 phenotype) in mice (Arkins et al., 1993) and with the M2 phenotype in human macrophages in vitro (Martinez et al., 2006). Hence, increased expression of IGFI in MDM-M0 from cows fed CrP may lead to increased production of IGF-I, which in turn may stimulate muscle regeneration, inducing resolution of inflammation (Tonkin et al., 2015). Whether the MDM-M2 phenotype is the primary monocyte enhancing muscle regeneration in cows fed $\mathrm{CrP}$ remains unknown and warrants further investigation. Our results suggest a potential role for $\mathrm{CrP}$ modulating the metabolism of resident macrophages.

Glucose is the preferred metabolic fuel during inflammation and plays a vital role in the proliferation, survival, and differentiation of phagocytic cells such as macrophages (Ingvartsen and Moyes, 2013). A higher expression of $S L C 2 A 3$ (coding for GLUT-3) compared with SLC2A1 (coding for GLUT-1) has been reported in MDM from non-lactating dairy cows (Eger et al., 2016) and supports our findings that regardless of Mtype, the expression of $S L C 2 A 3$ was greater, followed by $S L C 2 A 5$, and then $S L C 2 A 1$ (Supplemental Table S2; https://doi.org/10.3168/jds.2016-12079). This may be supported by the stage of lactation chosen for the current study (i.e., past the peak of lactation), as mRNA expression of GLUT-3 in monocytes increases with DIM (Eger et al., 2016). The greater expression of $S L C 2 A 3$ in MDM supports claims that GLUT-3 in monocytes and macrophages can compete for glucose when glucose concentrations are low (Fu et al., 2004), such as during the transition period for lactating dairy cows. This provides further support for future studies involving the potential benefits of $\mathrm{CrP}$ supplementation for the function of monocytes and macrophages for dairy cows during the transition period when glucose supply is low. The lack of effect of treatment on SLC2A1 expression in any of the 3 MDM phenotypes may indicate that GLUT-1 is not a critical glucose transporter in bovine macrophages, or the high demand of glucose for lactose synthesis in the mammary gland may result in increased expression of GLUT-3 to compete for glucose uptake when glucose in circulation is prioritized toward milk synthesis, or both. Moreover, in hypoglycemic compared with euglycemic humans, the 
expression of GLUT-3 on the monocyte cell surface was increased by 2.3 times, whereas that of GLUT- 1 was unchanged (Korgun et al., 2002). This may indicate altered expression of glucose transporters when glucose availability is low, such as the time around parturition. Therefore, future studies that examine the effect of Cr supplementation on glucose transport for resident macrophages from cows during the transition period are warranted.

\section{CONCLUSIONS}

This study is the first to characterize the effect of feeding $\mathrm{Cr}$ on the response of MDM from both primiparous and multiparous cows in mid lactation. Our results suggest that the effect of feeding $\mathrm{Cr}$ on MDM may be more marked for primiparous than for multiparous cows in mid lactation. The marginal differences observed may be partly attributable to the shorter duration of feeding time, physiological state, or stage of lactation. Future studies examining the effect of dietary $\mathrm{CrP}$ supplementation on the inflammatory response at different stages of lactation, feeding duration, physiological states, and parities is necessary to establish optimal feeding periods that maximize the effect of $\mathrm{CrP}$ supplementation on immune cell function.

\section{ACKNOWLEDGMENTS}

This study was funded by Kemin Industries Inc. (Des Moines, IA). The authors acknowledge the staff of the University of Maryland Dairy Research Unit (Clarksville) for their assistance with animal care and data collection. Gratitude is extended to the undergraduate students Rachel Gagliardi and Ian Doody for their laboratory assistance.

\section{REFERENCES}

AOAC International. 2000. Official Methods of Analysis. 17th ed. AOAC International, Arlington, VA.

AOAC International. 2006. Official Methods of Analysis. 18th ed. AOAC International, Arlington, VA.

Arkins, S., N. Rebeiz, A. Biragyn, D. L. Reese, and K. W. Kelley. 1993. Murine macrophages express abundant insulin-like growth factor-I class I Ea and Eb transcripts. Endocrinology 133:2334-2343.

Aschenbach, J. R., N. B. Kristensen, S. S. Donkin, H. M. Hammon, and G. B. Penner. 2010. Gluconeogenesis in dairy cows: The secret of making sweet milk from sour dough. IUBMB Life 62:869-877.

Bauman, D. E., and W. B. Currie. 1980. Partitioning of nutrients during pregnancy and lactation: A review of mechanisms involving homeostasis and homeorhesis. J. Dairy Sci. 63:1514-1529.

Bradford, B. J., K. Yuan, J. K. Farney, L. K. Mamedova, and J. A Carpenter. 2015. Invited review: Inflammation during the transition to lactation: New adventures with an old flame. J. Dairy Sci. 98:6631-6650.

Burton, J. L., B. A. Mallard, and D. N. Mowat. 1993. Effects of supplemental chromium on immune responses of periparturient and early lactation dairy cows. J. Anim. Sci. 71:1532-1539.
Calle, M. C., and M. L. Fernandez. 2012. Inflammation and type 2 diabetes. Diabetes Metab. 38:183-191.

Chang, X., B. A. Mallard, and D. N. Mowat. 1996. Effects of chromium on health status, blood neutrophil phagocytosis and in vitro lymphocyte blastogenesis of dairy cows. Vet. Immunol. Immunopathol. 52:37-52.

Eger, M., J. Hussen, M. Koy, S. Dänicke, H. J. Schuberth, and G. Breves. 2016. Glucose transporter expression differs between bovine monocyte and macrophage subsets and is influenced by milk production. J. Dairy Sci. 99:2276-2287.

Epelman, S., K. J. Lavine, and G. J. Randolph. 2014. Origin and functions of tissue macrophages. Immunity 41:21-35.

Fernández-Real, J. M., and J. C. Pickup. 2008. Innate immunity, insulin resistance and type 2 diabetes. Trends Endocrinol. Metab. 19:10-16.

Fu, Y., L. Maianu, B. R. Melbert, and W. T. Garvey. 2004. Facilitative glucose transporter gene expression in human lymphocytes, monocytes, and macrophages: A role for GLUT isoforms 1, 3, and 5 in the immune response and foam cell formation. Blood Cells Mol. Dis. 32:182-190.

Garcia, M., B. J. Bequette, and K. M. Moyes. 2015. Hepatic metabolic response of Holstein cows in early and mid lactation is altered by nutrient supply and lipopolysaccharide in vitro. J. Dairy Sci. 98:7102-7114.

George, J. W., J. Snipes, and V. M. Lane. 2010. Comparison of bovine hematology reference intervals from 1957 to 2006. Vet. Clin. Pathol. 39:138-148.

Hayirli, A., D. R. Bremmer, S. J. Bertics, M. T. Socha, and R. R. Grummer. 2001. Effect of chromium supplementation on production and metabolic parameters in periparturient dairy cows. J. Dairy Sci. 84:1218-1230.

Holtenius, P., and K. Holtenius. 2007. A model to estimate insulin sensitivity in dairy cows. Acta Vet. Scand. 49:29.

Ingvartsen, K. L., and K. Moyes. 2013. Nutrition, immune function and health of dairy cattle. Animal 7:112-122.

Italiani, P., and D. Boraschi. 2014. From monocytes to M1/M2 macrophages: Phenotypical vs. functional differentiation. Front. Immunol. 5:514.

Korgun, E. T., R. Demir, P. Sedlmayr, G. Desoye, G. M. Arikan, P. Puerstner, M. Haeusler, G. Dohr, G. Skofitsch, and T. Hahn. 2002. Sustained hypoglycemia affects glucose transporter expression of human blood leukocytes. Blood Cells Mol. Dis. 28:152-159.

Lee, B., L. Qiao, B. Kinney, G. S. Feng, and J. Shao. 2014. Macrophage depletion disrupts immune balance and energy homeostasis. PLoS One 9:e99575.

Leiva, T., R. F. Cooke, A. P. Brandão, A. C. Aboin, J. Ranches, and J. L. M. Vasconcelos. 2015. Effects of excessive energy intake and supplementation with chromium propionate on insulin resistance parameters, milk production, and reproductive outcomes of lactating dairy cows. Livest. Sci. 180:121-128.

Martinez, F. O. 2012. Analysis of gene expression and gene silencing in human macrophages. Curr. Protoc. Immunol. 96:14-28.

Martinez, F. O., S. Gordon, M. Locati, and A. Mantovani. 2006. Transcriptional profiling of the human monocyte-to-macrophage differentiation and polarization: New molecules and patterns of gene expression. J. Immunol. 177:7303-7311.

McNamara, J. P., and F. Valdez. 2005. Adipose tissue metabolism and production responses to calcium propionate and chromium propionate. J. Dairy Sci. 88:2498-2507.

Murray, P. J., J. E. Allen, S. K. Biswas, E. A. Fisher, D. W. Gilroy, S. Goerdt, S. Gordon, J. A. Hamilton, L. B. Ivashkiv, T. Lawrence, M. Locati, A. Mantovani, F. O. Martinez, J. L. Mege, D. M. Mosser, G. Natoli, J. P. Saeij, J. L. Schultze, K. A. Shirey, A. Sica, J. Suttles, I. Udalova, J. A. van Ginderachter, S. N. Vogel, and T. A. Wynn. 2014. Macrophage activation and polarization: Nomenclature and experimental guidelines. Immunity 41:14-20.

Murray, P. J., and T. A. Wynn. 2011. Protective and pathogenic functions of macrophage subsets. Nat. Rev. Immunol. 11:723-737.

NRC. 2001. Nutrient Requirements of Dairy Cattle. 7th rev. ed. Natl. Acad. Press, Washington, DC. 
Pfaffl, M. W. 2001. A new mathematical model for relative quantification in real-time RT-PCR. Nucleic Acids Res. 29:e45.

Pfaffl, M. W., A. Tichopad, C. Prgomet, and T. P. Neuvians. 2004. Determination of stable housekeeping genes, differentially regulated target genes and sample integrity: BestKeeper-Excel-based tool using pair-wise correlations. Biotechnol. Lett. 26:509-515.

Robinson, D. H., and H. Wainer. 2002. On the past and future of null hypothesis significance testing. J. Wildl. Manage. 66:263-271.

Spears, J. W., C. S. Whisnant, G. B. Huntington, K. E. Lloyd, R. S. Fry, K. Krafka, A. Lamptey, and J. Hyda. 2012. Chromium propionate enhances insulin sensitivity in growing cattle. J. Dairy Sci. 95:2037-2045.

Sumner, J. M., F. Valdez, and J. P. McNamara. 2007. Effects of chromium propionate on response to an intravenous glucose tolerance test in growing Holstein heifers. J. Dairy Sci. 90:3467-3474.

Tavakoli, S., D. Zamora, S. Ullevig, and R. Asmis. 2013. Bioenergetic profiles diverge during macrophage polarization: Implications for the interpretation of 18F-FDG PET imaging of atherosclerosis. J. Nucl. Med. 54:1661-1667.

Tonkin, J., L. Temmerman, R. D. Sampson, E. Gallego-Colon, L. Barberi, D. Bilbao, M. D. Schneider, A. Musaro, and N. Rosenthal. 2015. Monocyte/macrophage-derived IGF-1 orchestrates murine skeletal muscle regeneration and modulates autocrine polarization. Mol. Ther. 23:1189-1200.
Van Soest, P. J., J. B. Robertson, and B. A. Lewis. 1991. Methods for dietary fiber, neutral detergent fiber and non-starch polysaccharides in relation to animal nutrition. J. Dairy Sci. 74:3583-3597.

Vargas-Rodriguez, C. F., K. Yuan, E. C. Titgemeyer, L. K. Mamedova, K. E. Griswold, and B. J. Bradford. 2014. Effects of supplemental chromium propionate and rumen-protected amino acids on productivity, diet digestibility, and energy balance of peak-lactation dairy cattle. J. Dairy Sci. 97:3815-3821.

Walter, M. R., and D. W. Morck. 2002. In vitro expression of tumor necrosis factor-alpha, interleukin 1beta, and interleukin $8 \mathrm{mRNA}$ by bovine macrophages following exposure to Porphyromonas levii Can. J. Vet. Res. 66:93-98.

Yasui, T., J. A. A. McArt, C. M. Ryan, R. O. Gilbert, D. V. Nydam, F. Valdez, K. E. Griswold, and T. R. Overton. 2014. Effects of chromium propionate supplementation during the periparturient period and early lactation on metabolism, performance, and cytological endometritis in dairy cows. J. Dairy Sci. 97:6400-6410.

Yuan, K., C. F. Vargas-Rodriguez, L. K. Mamedova, M. B. Muckey, M. A. Vaughn, D. D. Burnett, J. M. Gonzalez, E. C. Titgemeyer, K. E. Griswold, and B. J. Bradford. 2014. Effects of supplemental chromium propionate and rumen-protected amino acids on nutrient metabolism, neutrophil activation, and adipocyte size in dairy cows during peak lactation. J. Dairy Sci. 97:3822-3831. 